\title{
Estrogen Signaling in Endometrial Cancer: a Key Oncogenic Pathway with Several Open Questions
}

\author{
Adriana C. Rodriguez ${ }^{1,2} \cdot$ Zannel Blanchard ${ }^{1,2} \cdot$ Kathryn A. Maurer ${ }^{1,3} \cdot$ Jason Gertz ${ }^{1,2}$ (D) \\ Received: 5 October 2018 / Accepted: 16 January 2019 / Published online: 2 February 2019 \\ (C) The Author(s) 2019
}

\begin{abstract}
Endometrial cancer is the most common gynecological cancer in the developed world, and it is one of the few cancer types that is becoming more prevalent and leading to more deaths in the USA each year. The majority of endometrial tumors are considered to be hormonally driven, where estrogen signaling through estrogen receptor $\alpha(E R)$ acts as an oncogenic signal. The major risk factors and some treatment options for endometrial cancer patients emphasize a key role for estrogen signaling in the disease. Despite the strong connections between estrogen signaling and endometrial cancer, important molecular aspects of ER function remain poorly understood; however, progress is being made in our understanding of estrogen signaling in endometrial cancer. Here, we discuss the evidence for the importance of estrogen signaling in endometrial cancer, details of the endometrial cancerspecific actions of ER, and open questions surrounding estrogen signaling in endometrial cancer.
\end{abstract}

Keywords Endometrial cancer $\cdot$ Estrogen receptor alpha $\cdot$ Estrogen signaling $\cdot$ Progesterone signaling $\cdot$ Gene regulation

\section{Introduction}

Uterine cancer is the fourth most common cancer in women, and the most common gynecological cancer, accounting for more than 60,000 cases and 10,000 deaths in the USA each year [1]. Endometrial cancer is the most common type of uterine cancer and is subdivided into two types by histopathology [2]. Type I endometrial tumors, also known as low grade endometrioid, make up the majority of endometrial cancer cases $(\sim 85 \%)$, are low grade with a glandular structure, usually express high levels of estrogen receptor $\alpha$ (ER), and are thought to be hormonally driven [3]. Type II tumors include high-grade endometrioid tumors, serous tumors, clear cell tumors,

Adriana C. Rodriguez and Zannel Blanchard contributed equally to this work.

Jason Gertz

jay.gertz@hci.utah.edu

1 Huntsman Cancer Institute, University of Utah, Salt Lake City, UT, USA

2 Department of Oncological Sciences, University of Utah School of Medicine, Salt Lake City, UT, USA

3 Department of Obstetrics and Gynecology, University of Utah School of Medicine, Salt Lake City, UT, USA carcinosarcomas, and tumors with mixed histology. These tumors are less likely to express ER [4, 5], have a worse prognosis, and share molecular features with triplenegative breast cancer and serous ovarian cancer, including a high prevalence of p53 mutations and high copy number variation [6]. Despite the worse prognosis of type II endometrial cancers, the hormonally driven type I endometrial cancers are responsible for more deaths because of their increased incidence [7].

Recent in-depth molecular analysis of large collections of endometrial tumors has provided additional resolution to the subtypes of the disease [8]. The Cancer Genome Atlas (TCGA) project integrated mutational analysis, copy number variation, and mRNA expression to identify four molecular subtypes: ultramutated - defined by POLE mutations, microsatellite instable, copy-number low, and copy-number high. Tumors from each of the four subtypes express high levels of ER, with the exception of copy-number high, which are type II endometrial tumors [8]. The histological and molecular subtypes of endometrial cancer both point to the potential for estrogen signaling through ER to be active in the majority of endometrial tumors. In this review, we discuss both the evidence that estrogen signaling plays a central role in endometrial cancer as well as the uncovered and yet to be discovered molecular details surrounding ER in the disease. 


\section{Estrogen-Associated Risk Factors for Endometrial Cancer}

Estrogens play a mitogenic role in the normal endometrium, driving tissue growth as part of pregnancy anticipation during the menstrual cycle. During the late follicular phase of the menstrual cycle, estrogens (particularly estrone and $17 \beta-$ estradiol, or E1 and E2, respectively) are produced by the developing follicle leading to growth of the endometrium [9]. Estrogen production peaks at ovulation, the end of the follicular phase, but is produced at lower levels by the corpus luteum during the mid- and late-luteal phase before dropping prior to menstruation [10]. The second wave of estrogens does not lead to endometrial cell proliferation, and this is due to the presence of progestogens, particularly progesterone. Progesterone levels are low during the follicular phase of the menstrual cycle but rise due to corpus luteum production in the mid- and late-luteal phase [11]. Progesterone inhibits estrogen-induced endometrial growth during the luteal phase while also transitioning the endometrium to a receptive state that is ready for blastocyst implantation. This balance between pro-growth estrogens and anti-growth progestogens is often dominated by estrogens during cancer formation. In animal models, high levels of estrogens unopposed by progesterone lead to endometrial hyperplasia or cancer [12-15], suggesting that the lack of estrogen/progesterone balance can contribute to the early stages of endometrial cancer formation.

Consistent with the fundamental role of estrogens and progestogens in growth of the endometrium, many of the endometrial cancer risk factors involve excess estrogens or estrogen signaling unopposed by progesterone signaling (Fig. 1). One of the most important and prevalent risk factors for endometrial cancer is obesity. Obese women have a 3-fold increased risk of developing endometrial cancer [16]. In a recent umbrella review of risk factors and endometrial cancer incidence, body mass index was strongly associated with increased cancer risk in premenopausal women (relative risk per $5 \mathrm{~kg} / \mathrm{m}^{2}=1.49$ ) and postmenopausal women (relative risk per $5 \mathrm{~kg} / \mathrm{m}^{2}=1.60$ ) [17]. The link between estrogens and obesity stems from adipose tissue's ability to synthesize estrogen [18]. In adipose tissue, both adipocytes and stromal cells express aromatase [19], the enzyme responsible for converting androgens to estrogens [20]. The excess estrogens produced by the adipose tissue provides a growth signal for the endometrium that is unopposed by progesterone. Obesity also leads to higher rates of anovulation [21] with a relative risk above 2 for body mass index greater than 29 [22]; however, most obese women have normal ovulatory menstrual cycles [23]. In anovulatory women, the lack of ovulation and corpus luteum production keeps progesterone levels low. Diminished progesterone is unable to execute important growth suppression of the estrogen stimulated endometrium [24], leading to unopposed growth of endometrial cells. Patients with polycystic ovarian syndrome
(PCOS) have an increased risk of endometrial cancer [25], and part of this risk likely relates to anovulation which again leads to estrogen signaling that is unopposed by progesterone signaling. Obesity is a risk factor for PCOS, although many nonobese women develop PCOS and many obese women do not exhibit PCOS. PCOS is also more complex than simply a reduction in progesterone; progesterone levels are not always reduced and the levels of other hormones can be affected [26]. In addition to obesity and PCOS, other risk factors include estrogen therapy without progestins [27], tamoxifen for the treatment of breast cancer (discussed below), parity, oral contraceptive use, cigarette smoking, age at menarche, and diabetes [7]. With the exception of genetic predisposition syndromes, such as Lynch syndrome [28] and Cowden syndrome [29], risk factors implicate estrogen signaling as a key driving force in endometrial cancer formation.

\section{Hormone Therapy for the Treatment of Endometrial Cancer}

The most common symptom of endometrial cancer is abnormal vaginal bleeding [30], which leads to most endometrial tumors being diagnosed at an early stage. Because of the early detection, surgical removal of the uterus and ovaries for type I endometrial tumors is very effective with only a minority of patients requiring adjuvant treatment, most commonly vaginal brachytherapy [31]. In the subset of patients with type I endometrial cancer who are either unable to undergo surgery or want to maintain fertility, progestins (synthetic progestogens) are given as the main course of treatment. Progestins work by binding to and activating progesterone receptor (PR). As discussed above, progestogens block estrogen-induced uterine growth and PR is thought to block the pro-growth actions of ER in a cell autonomous fashion in breast cancer cells by binding to similar sites and altering gene regulation [32]; however, it is unclear if a similar mechanism underlies the opposing effects of ER and PR in endometrial cancer cells. Progestin therapies have a strong initial response $(\sim 75 \%)$, and approximately half of young patients desiring uterinesparing treatment will be cancer free in the long term when treated with progestins alone $[33,34]$.

Despite the promising results of progestins for patients receiving uterine-sparing treatment, adjuvant hormone therapy has not been shown to confer benefit to endometrial cancer patients after surgery [35]. This lack of hormone therapy efficacy differs from breast cancer, where anti-estrogen therapies have decreased recurrence rates and improved overall survival [36, 37]. This difference is clinically intriguing and may be related to loss of ER expression in metastatic endometrial tumors, which arise from ER-positive primary tumors [38], which indicates the likely emergence of other oncogenic signals. Another 


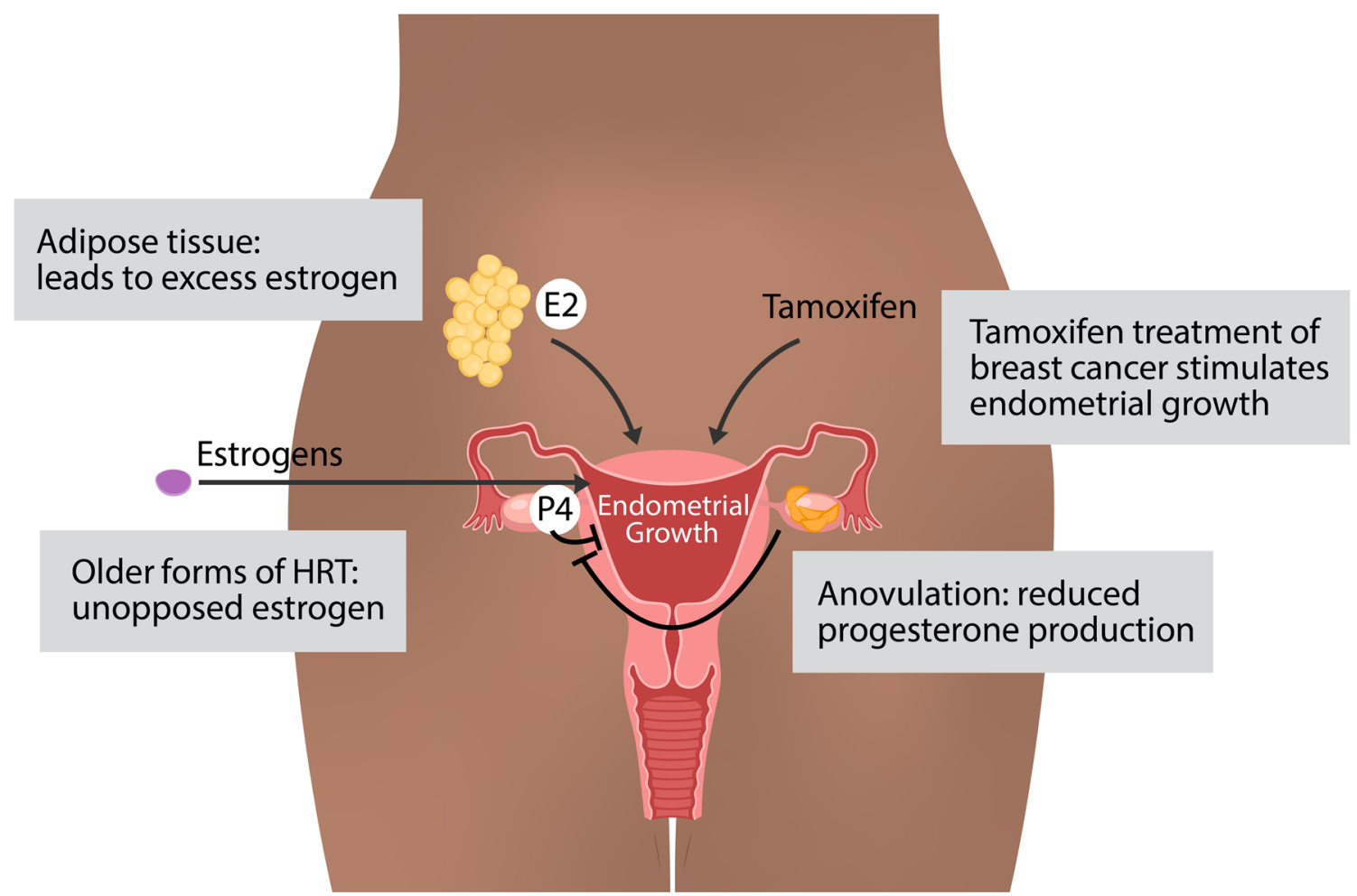

Fig. 1 Risk factors for endometrial cancer. In general, estrogens, including $17 \beta$-estradiol (E2), drive endometrial growth and progestogens, including progesterone (P4), block endometrial growth and promote differentiation. Excess estrogens can be caused by obesity, where adipose tissue can synthesize estrogens, estrogen only hormone

possible explanation for the lack of efficacy of adjuvant hormone therapy in type I endometrial cancer is the overall favorable prognosis; the already low recurrence rates may make it difficult to see significant differences in outcomes.

In the metastatic and recurrent setting, several endocrine therapies have been tried, including progestins, tamoxifen, aromatase inhibitors, and fulvestrant with varying response rates of 9-56\% [39-50]. Patients with lowgrade type I recurrent endometrial tumors are the best candidates for endocrine therapy with progestins being most commonly used [51] and providing variable response rates of between 11 and 37\% [52]. ER expressing tumors can also be treated with cycles of tamoxifen and progestins. The concept behind this treatment strategy is that tamoxifen leads to increased PR expression, which enables progestins to act on the tumor cells. The combination of tamoxifen and progestins exhibits similar response rates to progestins alone [53]. Fulvestrant and aromatase inhibitors have shown marginal efficacy in recurrent endometrial cancers [39]. Overall, endometrial cancer treatments reinforce the importance of steroid hormone signaling; however, with quite variable response rates, there is room for improvement in treating metastatic and recurrent endometrial cancer. replacement therapy (HRT), and breast cancer treatment with tamoxifen, which acts as a partial ER agonist in endometrial cells. Loss of progesterone, which can occur due to anovulation, can also contribute to endometrial growth

\section{Molecular Details of Estrogen Signaling Through Estrogen Receptor a in Endometrial Cancer}

In the early 1960s, work by Elwood Jensen found that E2 was specifically taken up by the immature rat uterus, which led to the hypothesis of an estrophilin that was later termed an estrogen receptor [54]. Twenty years later, the first human estrogen receptor, estrogen receptor $\alpha$ (ER), was cloned [55]. A decade after ER was cloned, a second estrogen receptor with a similar gene structure, named estrogen receptor $\beta$, was discovered [56]. ER and estrogen receptor $\beta$ are steroid hormone receptors that contain four key domains (in order from $\mathrm{N}$-terminal to C-terminal): Activation function 1 (AF-1) domain is involved in the recruitment of cofactors [57]; a C4-zinc DNA binding domain [58]; a hinge region that is required for synergy between AF-1 and activation function 2 (AF-2) in cofactor recruitment [59]; and a ligand-binding domain (LBD) that binds to estrogens with high affinity and recruits cofactors [60], the C-terminus of this domain is referred to as the AF2 domain and is critical for transcription activation [61]. ER and estrogen receptor $\beta$ share nearly identical DNA binding domains and more divergent ligand-binding domains with $60 \%$ homology [62]. There have been several studies on the expression and role of estrogen receptor $\beta$ in endometrial 
cancer with conflicting results (reviewed in [63]), but analysis of the TCGA data [8] suggests that ER is expressed at much higher levels (2.9-fold) on average than estrogen receptor $\beta$ in endometrial tumors.

Around the same time that estrogen receptor $\beta$ was identified, an unrelated $\mathrm{G}$ protein coupled receptor that bound E2 was also discovered $[64,65]$. GPER, G protein-coupled estrogen receptor also known as GPR30, is a G protein-coupled receptor that resides in the endoplasmic reticulum [66] and has high affinity for E2, but low affinity for the other native estrogens (E1 and estriol (E3)) [67]. GPER exhibits low expression in endometrial cancer cells that is 3 -fold lower on average than normal endometrial samples [8]. The low expression of GPER in endometrial tumors is consistent with a growth inhibitory role in endometrial cancer cells [68]. Of the three estrogen receptors encoded in the human genome, it is thought that the major mediator of pro-growth estrogen signaling in endometrial cancer cells is ER, because of its high expression and mitogenic role in other tissues and cancers.

Estrogen can signal through ER in a genomic and a nongenomic manner. Genomic signaling refers to ER carrying out its typical steroid hormone receptor action of estrogens causing ER to bind the genome and regulate transcription. In nongenomic signaling, ER is bound to the cell surface and when it binds estrogens, it activates other signaling pathways (e.g., cAMP, MAPK) [69]. This allows for more rapid responses than the genomic pathway. Nongenomic signaling can occur in the uterus [70], where it causes the rapid activation of IGF-1 receptor [71]. While the nongenomic actions of ER likely play a role in the normal endometrium and endometrial cancer, it has been shown that RNA synthesis is required for increased protein synthesis in response to estrogens in the uterus [72], and this review will focus on the genomic actions of ER.

In the following subsections, we discuss the different molecular aspects of genomic estrogen signaling through ER in endometrial cancer and often compare this knowledge to our understanding of ER's actions in breast cancer. Much of what we know concerning the molecular details of ER has come from extensive work in breast cancer, where ER has a clear oncogenic role. Despite the similar phenotypic consequences of estrogen signaling, many aspects of ER differ between breast and endometrial cancer and consequently many gaps in our knowledge of ER in endometrial cancer still exist (Fig. 2).

\section{ER Genome Binding}

Estrogen-bound ER is able to form homodimers that bind to estrogen response elements (EREs) in the genome [73]. ER's preferred sequence for an ERE is 5'-GGTCANNNTGACC-3', and each monomer of the dimer binds to one half site of the palindromic sequence $[74,75]$. Genome-wide analysis of ER binding using ChIP-seq has uncovered thousands of loci bound by ER after E2 induction [76]. The most common motif identified at these loci is the full palindromic ERE; however, the majority of bound sites do not have full palindromic sequence and usually harbor only half EREs instead [77]. The lack of an ERE at the majority of ER-bound sites across the genome was first observed in breast cancer cells but holds true in endometrial cancer cells as well [78]. There are two possible explanations for the non-ERE sites bound by ER. One explanation is that ER can bind to half EREs, which has been observed when an adjacent transcription factor is present (e.g., Sp1, AP-1) [79, 80]. Another explanation is ER binding to loci through protein-protein interactions only, a mechanism referred to as tethering. Tethering has been observed between ER and AP-1 factors as well as CREB1 [81]. Both of these mechanisms likely explain most ER binding sites and while they have not been directly shown in endometrial cancer cells, sequence analysis and modeling of ER-bound loci support these alternative binding modes [78]. The majority of ERbound loci not containing full EREs is not due to a lack of EREs in the genome. There are approximately 25,000 palindromic EREs in the human genome, but only $\sim 10 \%$ are bound in a given cell type [77, 78]. The lack of ER binding at most EREs is likely due to the local chromatin environment as the unbound sites are in regions of inaccessible chromatin [77] and harbor DNA methylation [78].

While the properties that govern ER binding site selection are most likely universal across cell types and organisms, ER binds to the genome in a highly cell type-specific manner. ER drives increased proliferation in both breast and endometrial cancer cells; however, ER's genomic binding targets and the resulting gene expression changes are very different between these cell types. The difference in loci bound by ER in breast and endometrial cancer cells was first observed in cell lines $[78,82]$ and later confirmed in patient tissues [83] where 15 $30 \%$ of ER binding sites are shared between breast cancer and endometrial cancer cells. The cell type-specific binding of ER is most likely caused by differences in the chromatin landscape between cell types. As a type I nuclear receptor that is generally restricted from binding the genome in the absence of estrogens, ER is unable to maintain accessible chromatin for its own binding and instead needs to identify binding sites each time it is activated by estrogens. This feature of ER biology manifests in the majority of ER's binding sites being found in regions of the genome that are accessible prior to E2 treatment based on the presence of DNase I hypersensitive sites [78, 84]. Since the chromatin landscape is inherently different between breast and endometrial cancer cells due to different developmental lineages and a different cadre of transcription factors, this leads to different ER binding profiles and therefore different target genes (Fig. 2).

ER binds primarily to promoter-distal regulatory regions; approximately $95 \%$ of ER-bound regions are at least $5 \mathrm{~kb}$ 


\section{BREAST CANCER}

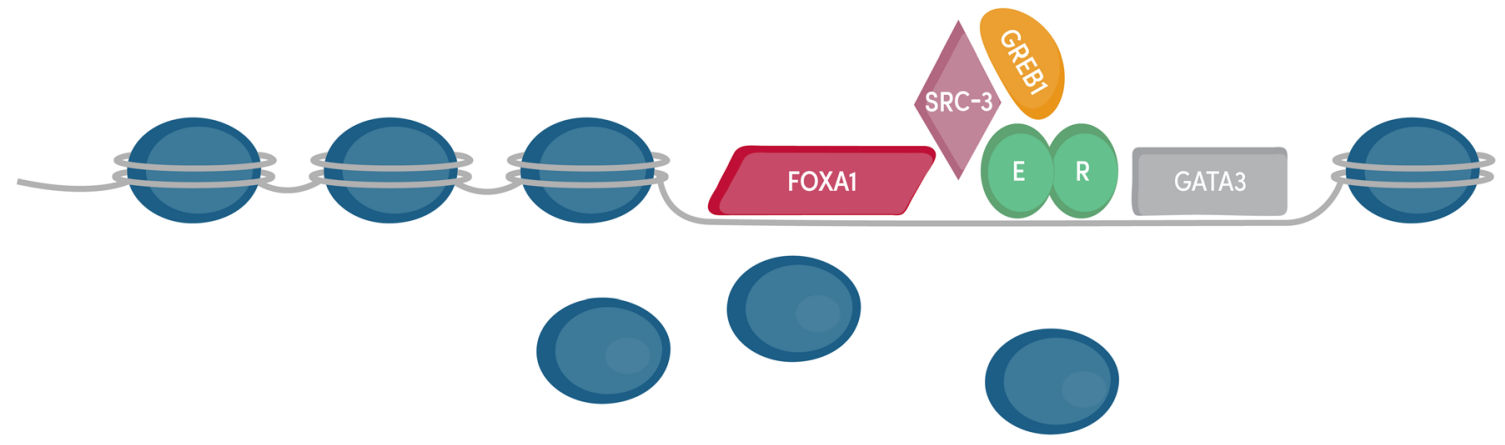

ENDOMETRIAL CANCER

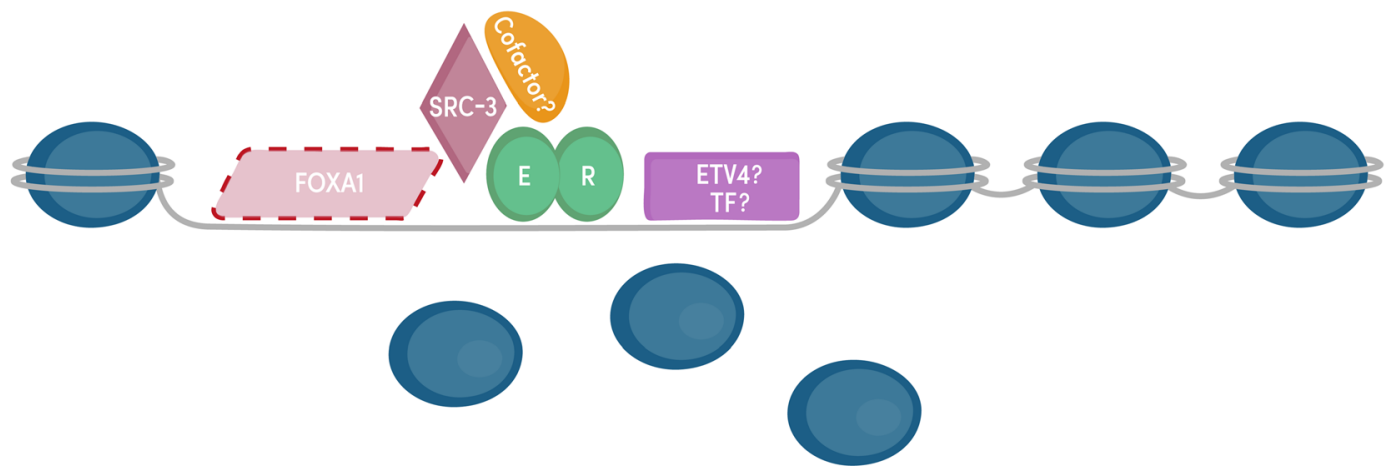

Fig. 2 ER's coregulatory proteins and genomic binding sites differ between endometrial cancer and breast cancer cells. ER binds to mostly different locations in endometrial and breast cancer cells and the majority of these differentially bound loci exhibit differential chromatin accessibility. FOXA1 and GATA3 play a key role in enabling ER

from any promoter $[85,86]$. Owing to the promoter distal binding of ER, most estrogen induced transcription is driven primarily by gene expression enhancers. These enhancers communicate to target gene promoters through long-range looping interactions. ER is directly involved in these looping interactions, and around $10 \%$ of all ER-bound sites have some evidence of looping to another region while ER is bound, based on ChIA-PET data [87]. Consistent with this observation, there are approximately 10 -fold more ER-bound sites than genes that change expression in response to E2 treatment in both endometrial cancer and breast cancer cells [78]. The overabundance of ER binding sites could be attributed to not every ER-bound site having the potential to contribute to the acute transcriptional response to estrogens. For example, sites without EREs may not contribute to gene expression, which was postulated based on work with ER DNA binding mutants in the mouse uterus [88]. Correlative studies have identified enhancer RNA production [89] and increases in DNase I hypersensitivity [84] as being associated with expression genomic binding in breast cancer, but the corresponding transcription factors (TF) in endometrial cancer remain unknown with FOXA1 playing a minor role. While some ER cofactors (e.g., SRC-3) are shared between breast and endometrial cancer, it is unclear if endometrial cancerspecific ER cofactors exist changes of nearby genes in breast cancer cells, again suggesting that some ER-bound loci have higher regulatory potential than others. Another reason underlying the overabundance of ER binding sites relative to genes is that most genes that are upregulated by E2 harbor multiple ER-bound sites within 100 kilobase pairs of their transcription start sites in both breast and endometrial cancer cells [90]. This observation indicates that many E2 responsive genes could be regulated by multiple ER-bound enhancers. To investigate how multiple ER-bound sites combine to regulate gene expression, Carleton et al. developed enhancer interference, a technique for testing the necessity of enhancers [91]. At each of the three genes tested in endometrial cancer cells, ER-bound sites combine in a synergistic/cooperative fashion to regulate gene expression. At these genes, the presence of a full ERE and being closer to the transcription start site were associated with the importance of a site [90]. While ERE containing enhancers were the most important sites, non-ERE ER-bound enhancers did play a role in supporting the ERE containing enhancers. More 
work in this area is needed in order to understand the relationship between ER genome binding and gene expression.

\section{Control of Tissue-Specific Transcriptional Responses to Estrogens}

ER's preferential binding to already accessible chromatin implies the need for other transcription factors to initially bind and create these accessible regions. Pioneer factors are sequence-specific transcription factors capable of binding to condensed chromatin and increasing accessibility at their binding sites, which allows other transcription factors and regulatory cofactors to bind. In breast cancer cells, FOXA1 [92] and GATA3 [93] act as pioneer factors for ER and are responsible for maintaining chromatin accessibility at many of ER's genomic binding sites (Fig. 2). In endometrial cancer cells, it is unclear which pioneer factors are responsible for enabling ER genomic binding. FOXA1 is expressed in some endometrial tumors and a role for FOXA1 as a pioneer factor in endometrial cancer cells has been proposed [83]; however, FOXA1 overlaps with less than $10 \%$ of ER-bound sites in endometrial cancer cells [78] and tumors [83], indicating that the pioneering role is minimal and does not explain most endometrial cancer-specific ER genomic binding. The tissue specificity of ER genomic binding and chromatin accessibility patterns implies an undiscovered endometrial cancer-specific pioneer factor. Motif analysis of endometrial cancer-specific ER-bound sites, along with gene expression analysis, found that the ETS family member, ETV4, may play a role in ER genomic binding and overlaps with $\sim 45 \%$ of ER binding sites [78]; however, this association has not been functionally evaluated. The mechanisms underlying ER's unique genomic binding pattern in endometrial cancer cells remain unclear (Fig. 2).

The regulation of ER's target genes is not only determined by where ER binds but also by the interacting proteins recruited to those sites. ER is capable of binding to cofactors through both the AF-1 and AF-2 domains, acting synergistically in the recruitment of coregulators [94]. Investigation of coregulators of steroid hormone receptors began in the 1990s and has led to the discoveries of coactivators such as the p160 family (known as SRCs or NCOAs) [95-97] and corepressors such as N-CoR and SMRT [98, 99] (Fig. 2). Most of these coregulators are only able to bind to sites when ER is present [100]. Helix 12 of the ligand binding domain is needed for ER's interactions with many of these cofactors. Crystal structures show that helix 12 lays across the ligand binding pocket when an agonist is bound, generating a surface amenable for the binding of LXXLL motifs found on coregulators [57, 101]. In this manner, estrogen binding and cofactor recruitment are coordinated. Though these coregulators should be able to interact with ER independent of the cell type, cofactors can contribute to the tissue-specific gene regulation by ER through differential expression between tissues.

Differences in cofactor usage could also lead to tissuespecific responses to hormone therapies. Tamoxifen is a commonly prescribed hormone therapy for the treatment of breast cancer and has been effective at reducing recurrence in women with ER-positive breast cancer. Unfortunately, tamoxifen has numerous reported side effects, including a $\sim 7$-fold increased risk of endometrial cancer in postmenopausal women [102]. In breast cancer cells, tamoxifen acts mostly as an antagonist by binding to the same pocket as E2 and dislocating helix 12 from the ligand-binding domain [103]. However, in endometrial cancer cells, tamoxifen has estrogenic properties and acts as a partial agonist [104]. While the tissue-specific actions of tamoxifen are not fully understood, one model is that the complement of cofactors differs between breast cancer cells and normal endometrial cells and that the binding of some cofactors is blocked by tamoxifen while other cofactors are unaffected [105]. When endometrial cancer arises during tamoxifen treatment, transcription regulation through ER can be altered. ER genomic binding in endometrial cancers that arose after tamoxifen treatment of breast cancer look more like ER binding in breast tumors when compared to ER binding in tamoxifen unassociated endometrial tumors, but the effect is subtle with ER binding across all endometrial tumors clustering together and away from the breast tumors regardless of tamoxifen treatment [106]. The opposing effects of tamoxifen highlight a key difference between breast and endometrial cells that might be due to which coregulators are expressed and used by ER.

While many ER cofactors are known, new methods such as rapid immunoprecipitation and mass spectrometry of endogenous proteins (RIME) have been used to discover other proteins found in the vicinity of ER [107]. RIME is similar to ChIP-seq with the exception that instead of extracting and sequencing DNA after ChIP, proteins are extracted and identified by mass spectrometry. This technique was used to discover a novel cofactor in breast cancer cells, GREB1, which is necessary for stabilizing ER's interaction with other cofactors [107] (Fig. 2). RIME and similar techniques, such as Bio-ID and APEX [108, 109], will be useful in uncovering endometrial cancer-specific ER cofactors or cofactors that are more commonly used in endometrial cancer cells than breast cancer cells.

\section{Interplay with Other Steroid Hormone Receptors}

Steroid hormone receptors can bind to similar sequences and influence the action of one another [110]. Vahrenkamp et al. recently performed analysis of the association between steroid hormone receptor expression at the mRNA level and outcomes of endometrial cancer patients based on TCGA data [111]. While almost all type I endometrial tumors express 
ER, higher expression is associated with better outcomes. This association is likely due to high ER expression indicating a hormonally driven tumor that is more differentiated. Not surprisingly, high PR expression is also associated with better prognosis. The expression of ER and PR is highly correlated in endometrial tumors and ER directly regulates PR expression [112]. PR is also able to modulate ER's gene regulatory role in breast cancer cells as cotreatment with estradiol and a progestin rewires ER genomic binding by causing it to bind to PR-bound sites [113, 114]. A similar relationship might be occurring in endometrial cancer cells where PR blocks ER's ability to drive growth. The only steroid hormone receptor whose expression is associated with worse outcomes in type I endometrial cancer is glucocorticoid receptor (GR), and this association is only seen in tumors that express high levels of ER [111]. The poor prognosis of tumors with high GR expression is surprising because corticosteroids, which bind to and activate GR, cause growth suppression in the normal uterus $[115,116]$. GR-mediated growth suppression is no longer achieved in endometrial hyperplasia and endometrial cancer cells. The loss in growth suppression is accompanied by reprogramming of GR genomic binding in endometrial cancer cells cotreated with E2 and dexamethasone, a synthetic corticosteroid, in which GR binding is moved to sites normally bound by ER [111]. In contrast to findings in endometrial cancer, GR expression is associated with better prognosis in ER-positive breast cancer [117] and GR reprograms ER genomic binding instead [118]. These examples show that steroid hormone receptors can have profound phenotypic and molecular effects on each other; however, more work is needed to uncover how ER, PR, and GR influence one another in endometrial cancer.

\section{Estrogen Receptor a Mutations Cause Estrogen-Independent Estrogen Receptor a Activity}

Mutations in the LBD of ER were initially reported over two decades ago in breast cancer cells $[119,120]$ and tumors [121]. However, they remained a relatively underexplored phenomenon until recently. The advent of newer generation, deep sequencing technologies has led to the discovery of ER mutations in approximately $15 \%$ of metastatic ER-positive breast tumors [122]. Although other ER mutations have been identified at lower frequencies, the most predominant LBD mutations occur within helix 12 , mainly affecting three amino acids in that region: L536, Y537, and D538. Studies have shown a clear association between these heterozygous, activating mutations and acquired hormone therapy resistance [122-131]. Interestingly, the mutations are observed in less than $1 \%$ of primary breast tumors and are not thought to drive breast tumor initiation [122]. ER mutations are more prevalent in primary endometrial cancer, with $5.8 \%$ of tumors harboring an ER mutation [132], representing approximately 3500 new ER mutant endometrial cancer diagnoses in the USA each year.

Advances in genome editing technologies have enabled in depth studies into the consequences of ER LBD mutations. Functional studies in breast cancer indicate these mutations confer estrogen-independent activity to ER, increasing proliferation and driving gene expression in the absence of estrogens, both in vitro and in vivo [122, 125-130]. Mutant ER's modified/active conformation not only leads to constitutive receptor activity, but also a decreased sensitivity to hormone therapies [122, 123, 129, 130,133]. The discovery of estrogenindependent ER activity in ER mutant breast cancer is consistent with the observation that endometrial cancer patients with ER mutant tumors have lower body mass indexes than patients with ER wild-type tumors [134], indicating that excess estrogens may not play as large a role in ER mutant tumor formation. Evaluation of an endometrial cancer cell model of the D538G mutation found that mutant ER exhibits estrogenindependent genomic binding as well as an expanded set of genomic binding sites [135]. The constitutively active mutant receptor creates a more open and accessible chromatin landscape in endometrial cancer cells, implying a potential small pioneering role for mutant ER in this disease. Mutant ER causes gene expression changes that are a combination of estrogenindependent regulation of genes normally responsive to E2 and novel regulation of genes that are not responsive to E2. These transcriptional changes are distinct from those observed in ER mutant breast cancer cells; however, similar pathways such as growth and migration are impacted $[135,136]$. Understanding the molecular and pathological impact of ER mutations in endometrial cancer will further our knowledge of ER mutant disease and could uncover treatment options for patients with ER mutant tumors, which trend towards worse prognosis [134].

\section{Outstanding Challenges Surrounding the Role of Estrogen Signaling in Endometrial Cancer}

There are several open questions regarding estrogen signaling in endometrial cancer. As discussed above, there are clear signs that ER genomic binding is controlled by different and yet unknown transcription factors in endometrial cancer cells as compared to breast cancer cells. In addition, the cofactors that are utilized in endometrial cancer cells appear to differ from breast cancer cells. Studies into endometrial cancerspecific transcription factors and cofactors are sure to uncover interesting biology and shed light on how cell type-specific gene regulation through ER occurs. The discovery of endometrial cancer-specific ER influencing transcription factors and ER binding cofactors may also uncover clinical vulnerabilities that could be exploited in the treatment of endometrial cancer [137]. 
The treatment options for endometrial cancer are limited and, until recently, have remained relatively unchanged. According to the FDA, only one hormonally active drug is approved for use in endometrial cancer: megestrol acetate, a progestin. In contrast, over 50 drugs, including several hormone therapies, are approved for use in breast cancer. While progestins are effective in fertility sparing treatment of primary type I endometrial tumors, the recurrence rate is still close to $50 \%$ [33]. A greater understanding of how ER functions in endometrial cancer cells could identify additional treatments that work to block ER's ability to drive growth. In the metastatic setting, there is a need for targeted therapies that effectively treat recurrent tumors and further study of estrogen signaling in endometrial cancer could help identify successful drugs for a subset of metastatic endometrial cancer patients. Patients with ER mutant tumors might require different treatment strategies, as it is unclear if these tumors respond to progestin and if they are inherently more aggressive. There is hope for new therapies being adopted for use in endometrial cancer as pembrolizumab was recently approved for the treatment of microsatellite instable or mismatch repair deficient advanced endometrial cancer.

While excessive estrogen signaling plays a role in endometrial cancer formation, common genomic alterations are also observed. Mutations in PTEN, ARID1A, PIK3CA, PIK3R1, beta-catenin, $C T C F$, and $K R A S$, are often found in endometrial tumors with endometrioid histology [8, 138], with a mutation in at least one of these genes found in $94 \%$ of tumors. Many of these genes appear to be specific to endometrioid endometrial tumors, as opposed to nonendometrioid endometrial tumors, including transcriptional regulators $A R I D 1 A$, beta-catenin, and $C T C F$, indicating that there may be a connection between these mutations and estrogen signaling. Alterations in signaling pathways can alter ER genomic binding and target genes in breast cancer cells [139, 140], and it would be interesting to discover how endometrial cancer genomic alterations impact how ER regulates gene expression. Along the same lines, ER genomic binding could be a read out for the activity of other signaling pathways and therefore could be used to predict prognosis, as ER binding in breast tumors correlates with aggressiveness of the tumors [141]. An understanding of how endometrial cancer mutations influence estrogen signaling could uncover valuable information concerning crosstalk between environmental and genetic factors of the disease while also informing treatment decisions in endometrial cancer.

Unfortunately, progress has been slow in the clinical management of endometrial cancer and this is correlated with a lack of research funding devoted to understanding and combating the disease. Only $0.3 \%$ of the National Cancer Institute's fiscal year 2017 research funding went towards endometrial cancer research; however, uterine cancer represents $3.6 \%$ of cancer cases and $1.9 \%$ of cancer deaths. There is currently no Department of Defense Congressionally
Directed Medical Research Program (a program that supports research on many different cancer types) that funds endometrial cancer research. Endometrial cancer cases and deaths are on the rise [142], and it is becoming critical that more research, and more funding, are devoted to increasing our understanding of the disease and developing new treatment options for patients with endometrial cancer.

Acknowledgements We thank the Communications team at the Huntsman Cancer Institute for help with figures.

Funding This work was supported by a DOD Breast Cancer Research Program Breakthrough Award to J.G., NIH/NHGRI R01 HG008974 to J.G., and the Huntsman Cancer Institute (Comprehensive Cancer Center award from NIH/National Cancer Institute: P30 CA042014).

Open Access This article is distributed under the terms of the Creative Commons Attribution 4.0 International License (http:// creativecommons.org/licenses/by/4.0/), which permits unrestricted use, distribution, and reproduction in any medium, provided you give appropriate credit to the original author(s) and the source, provide a link to the Creative Commons license, and indicate if changes were made.

Publisher's Note Springer Nature remains neutral with regard to jurisdictional claims in published maps and institutional affiliations.

\section{References}

1. SEER Cancer Stat Facts: Uterine cancer. National Cancer Institute Bethesda M, https://seer.cancer.gov/statfacts/html/corp.html. Accessed Oct 2018

2. Bokhman JV (1983) Two pathogenetic types of endometrial carcinoma. Gynecol Oncol 15(1):10-17

3. Carlson MJ, Thiel KW, Leslie KK (2014) Past, present, and future of hormonal therapy in recurrent endometrial cancer. Int $\mathrm{J}$ Women's Health 6:429-435. https://doi.org/10.2147/IJWH. $\mathrm{S} 40942$

4. Jongen V, Briet J, de Jong R, ten Hoor K, Boezen M, van der Zee A, Nijman H, Hollema H (2009) Expression of estrogen receptor-alpha and -beta and progesterone receptor-A and -B in a large cohort of patients with endometrioid endometrial cancer. Gynecol Oncol 112(3):537-542. https://doi.org/10.1016/j.ygyno.2008.10.032

5. Shen F, Gao Y, Ding J, Chen Q (2017) Is the positivity of estrogen receptor or progesterone receptor different between type 1 and type 2 endometrial cancer? Oncotarget 8(1):506-511. https://doi. org/10.18632/oncotarget.13471

6. Berger AC, Korkut A, Kanchi RS, Hegde AM, Lenoir W, Liu W, Liu Y, Fan H, Shen H, Ravikumar V, Rao A, Schultz A, Li X, Sumazin P, Williams C, Mestdagh P, Gunaratne PH, Yau C, Bowlby R, Robertson AG, Tiezzi DG, Wang C, Cherniack AD, Godwin AK, Kuderer NM, Rader JS, Zuna RE, Sood AK, Lazar AJ, Ojesina AI, Adebamowo C, Adebamowo SN, Baggerly KA, Chen TW, Chiu HS, Lefever S, Liu L, MacKenzie K, Orsulic S, Roszik J, Shelley CS, Song Q, Vellano CP, Wentzensen N, Weinstein JN, Mills GB, Levine DA, Akbani R, Cancer Genome Atlas Research N (2018) A comprehensive pan-cancer molecular study of gynecologic and breast cancers. Cancer Cell 33(4):690 705 e9. https://doi.org/10.1016/j.ccell.2018.03.014

7. Setiawan VW, Yang HP, Pike MC, SE MC, Yu H, Xiang YB, Wolk A, Wentzensen N, Weiss NS, Webb PM, van den Brandt 
PA, van de Vijver K, Thompson PJ, Strom BL, Spurdle AB, Soslow RA, Shu XO, Schairer C, Sacerdote C, Rohan TE, Robien K, Risch HA, Ricceri F, Rebbeck TR, Rastogi R, Prescott J, Polidoro S, Park Y, Olson SH, Moysich KB, Miller AB, ML MC, Matsuno RK, Magliocco AM, Lurie G, Lu L, Lissowska J, Liang X, Lacey JV Jr, Kolonel LN, Henderson BE, Hankinson SE, Hakansson N, Goodman MT, Gaudet MM, Garcia-Closas M, Friedenreich CM, Freudenheim JL, Doherty J, De Vivo I, Courneya KS, Cook LS, Chen C, Cerhan JR, Cai H, Brinton LA, Bernstein L, Anderson KE, Anton-Culver H, Schouten LJ, Horn-Ross PL, Australian National Endometrial Cancer Study G (2013) Type I and II endometrial cancers: have they different risk factors? J Clin Oncol : Official Journal of the American Society of Clinical Oncology 31(20):2607-2618. https://doi.org/10.1200/JCO.2012.48.2596

8. Kandoth C, Schultz N, Cherniack AD, Akbani R, Liu Y, Shen H, Robertson AG, Pashtan I, Shen R, Benz CC, Yau C, Laird PW, Ding L, Zhang W, Mills GB, Kucherlapati R, Mardis ER, Levine DA, Cancer Genome Atlas Research N (2013) Integrated genomic characterization of endometrial carcinoma. Nature 497(7447):6773. https://doi.org/10.1038/nature12113

9. Groothuis PG, Dassen HH, Romano A, Punyadeera C (2007) Estrogen and the endometrium: lessons learned from gene expression profiling in rodents and human. Hum Reprod Update 13(4): 405-417. https://doi.org/10.1093/humupd/dmm009

10. Reed BG, Carr BR (2000) The normal menstrual cycle and the control of ovulation. In: De Groot LJ, Chrousos G, Dungan K, Feingold KR, Grossman A, Hershman JM, Koch C, Korbonits M, McLachlan R, New M, Purnell J, Rebar R, Singer F, Vinik A (eds) Endotext. MDText.com, Inc., South Dartmouth

11. Mesen TB, Young SL (2015) Progesterone and the luteal phase: a requisite to reproduction. Obstet Gynecol Clin N Am 42(1):135151. https://doi.org/10.1016/j.ogc.2014.10.003

12. Erdemoglu E, Guney M, Giray SG, Take G, Mungan T (2009) Effects of metformin on mammalian target of rapamycin in a mouse model of endometrial hyperplasia. Eur J Obstet Gynecol Reprod Biol 145(2):195-199. https://doi.org/10.1016/j.ejogrb. 2009.04.034

13. Newbold RR, Bullock BC, McLachlan JA (1990) Uterine adenocarcinoma in mice following developmental treatment with estrogens: a model for hormonal carcinogenesis. Cancer Res 50(23): $7677-7681$

14. Vollmer G (2003) Endometrial cancer: experimental models useful for studies on molecular aspects of endometrial cancer and carcinogenesis. Endocr Relat Cancer 10(1):23-42

15. Yang CH, Almomen A, Wee YS, Jarboe EA, Peterson CM, JanatAmsbury MM (2015) An estrogen-induced endometrial hyperplasia mouse model recapitulating human disease progression and genetic aberrations. Cancer Med 4(7):1039-1050. https://doi.org/ 10.1002/cam4.445

16. Dobbins M, Decorby K, Choi BC (2013) The association between obesity and cancer risk: a meta-analysis of observational studies from 1985 to 2011. ISRN Prev Med 2013:680536. https://doi.org/ $10.5402 / 2013 / 680536$

17. Raglan O, Kalliala I, Markozannes G, Cividini S, Gunter MJ, Nautiyal J, Gabra H, Paraskevaidis E, Martin-Hirsch P, Tsilidis KK, Kyrgiou M (2018) Risk factors for endometrial cancer: an umbrella review of the literature. Int J Cancer. https://doi.org/10. 1002/ijc. 31961

18. Hemsell DL, Grodin JM, Brenner PF, Siiteri PK, MacDonald PC (1974) Plasma precursors of estrogen. II. Correlation of the extent of conversion of plasma androstenedione to estrone with age. $\mathrm{J}$ Clin Endocrinol Metab 38(3):476-479. https://doi.org/10.1210/ jcem-38-3-476

19. Cleland WH, Mendelson CR, Simpson ER (1983) Aromatase activity of membrane fractions of human adipose tissue stromal cells and adipocytes. Endocrinology 113(6):2155-2160. https://doi. org/10.1210/endo-113-6-2155

20. Santen RJ, Brodie H, Simpson ER, Siiteri PK, Brodie A (2009) History of aromatase: saga of an important biological mediator and therapeutic target. Endocr Rev 30(4):343-375. https://doi. org/10.1210/er.2008-0016

21. Giviziez CR, Sanchez EG, Approbato MS, Maia MC, Fleury EA, Sasaki RS (2016) Obesity and anovulatory infertility: a review. JBRA Assist Reprod 20(4):240-245. https://doi.org/10.5935/ 1518-0557.20160046

22. Rich-Edwards JW, Spiegelman D, Garland M, Hertzmark E, Hunter DJ, Colditz GA, Willett WC, Wand H, Manson JE (2002) Physical activity, body mass index, and ovulatory disorder infertility. Epidemiology 13(2):184-190

23. Silvestris E, de Pergola G, Rosania R, Loverro G (2018) Obesity as disruptor of the female fertility. Reprod Biol Endocrinol 16(1): 22. https://doi.org/10.1186/s12958-018-0336-Z

24. Kurita T, Young P, Brody JR, Lydon JP, O'Malley BW, Cunha GR (1998) Stromal progesterone receptors mediate the inhibitory effects of progesterone on estrogen-induced uterine epithelial cell deoxyribonucleic acid synthesis. Endocrinology 139(11):47084713. https://doi.org/10.1210/endo.139.11.6317

25. Daniilidis A, Dinas K (2009) Long term health consequences of polycystic ovarian syndrome: a review analysis. Hippokratia 13(2):90-92

26. Deng Y, Zhang Y, Li S, Zhou W, Ye L, Wang L, Tao T, Gu J, Yang Z, Zhao D, Gu W, Hong J, Ning G, Liu W, Wang W (2017) Steroid hormone profiling in obese and nonobese women with polycystic ovary syndrome. Sci Rep 7(1):14156. https://doi.org/10.1038/ s41598-017-14534-2

27. Antunes CM, Strolley PD, Rosenshein NB, Davies JL, Tonascia JA, Brown C, Burnett L, Rutledge A, Pokempner M, Garcia R (1979) Endometrial cancer and estrogen use. Report of a large case-control study. N Engl J Med 300(1):9-13. https://doi.org/ 10.1056/NEJM197901043000103

28. Meyer LA, Broaddus RR, Lu KH (2009) Endometrial cancer and Lynch syndrome: clinical and pathologic considerations. Cancer Control 16(1):14-22. https://doi.org/10.1177/ 107327480901600103

29. Gammon A, Jasperson K, Champine M (2016) Genetic basis of Cowden syndrome and its implications for clinical practice and risk management. Appl Clin Genet 9:83-92. https://doi.org/10. 2147/TACG.S41947

30. Denschlag D, Ulrich U, Emons G (2010) The diagnosis and treatment of endometrial cancer: progress and controversies. Dtsch Arztebl Int 108(34-35):571-577. https://doi.org/10.3238/arztebl. 2011.0571

31. Dinkelspiel HE, Wright JD, Lewin SN, Herzog TJ (2013) Contemporary clinical management of endometrial cancer. Obstet Gynecol Int 2013:583891. https://doi.org/10.1155/2013/ 583891

32. Carroll JS, Hickey TE, Tarulli GA, Williams M, Tilley WD (2017) Deciphering the divergent roles of progestogens in breast cancer. Nat Rev Cancer 17(1):54-64. https://doi.org/10.1038/nrc.2016. 116

33. Gallos ID, Yap J, Rajkhowa M, Luesley DM, Coomarasamy A, Gupta JK (2012) Regression, relapse, and live birth rates with fertility-sparing therapy for endometrial cancer and atypical complex endometrial hyperplasia: a systematic review and metaanalysis. Am J Obstet Gynecol 207(4):266 e1-12. https:/ doi.org/10.1016/j.ajog.2012.08.011

34. Baker J, Obermair A, Gebski V, Janda M (2012) Efficacy of oral or intrauterine device-delivered progestin in patients with complex endometrial hyperplasia with atypia or early endometrial adenocarcinoma: a meta-analysis and systematic review of the literature. 
Gynecol Oncol 125(1):263-270. https://doi.org/10.1016/j.ygyno. 2011.11.043

35. Gien L, Kwon J, Oliver TK, Fung-Kee-Fung M (2008) Adjuvant hormonal therapy for stage I endometrial cancer. Curr Oncol 15(3):126-135

36. Jordan VC (2014) Tamoxifen as the first targeted long-term adjuvant therapy for breast cancer. Endocr Relat Cancer 21(3):R235R246. https://doi.org/10.1530/ERC-14-0092

37. Tremont A, Lu J, Cole JT (2017) Endocrine therapy for early breast cancer: updated review. Ochsner J 17(4):405-411

38. Bartosch C, Monteiro-Reis S, Vieira R, Pereira A, Rodrigues M, Jeronimo C, Lopes JM (2015) Endometrial endometrioid carcinoma metastases show decreased ER-alpha and PR-A expression compared to matched primary tumors. PLoS One 10(8): e0134969. https://doi.org/10.1371/journal.pone.0134969

39. Battista MJ, Schmidt M (2016) Fulvestrant for the treatment of endometrial cancer. Expert Opin Investig Drugs 25(4):475-483. https://doi.org/10.1517/13543784.2016.1154532

40. Asbury RF, Brunetto VL, Lee RB, Reid G, Rocereto TF, Gynecologic OG (2002) Goserelin acetate as treatment for recurrent endometrial carcinoma: a Gynecologic Oncology Group study. Am J Clin Oncol 25(6):557-560

41. Fiorica JV, Brunetto VL, Hanjani P, Lentz SS, Mannel R, Andersen W, Gynecologic Oncology Groups (2004) Phase II trial of alternating courses of megestrol acetate and tamoxifen in advanced endometrial carcinoma: a Gynecologic Oncology Group study. Gynecol Oncol 92(1):10-14

42. Lentz SS, Brady MF, Major FJ, Reid GC, Soper JT (1996) Highdose megestrol acetate in advanced or recurrent endometrial carcinoma: a Gynecologic Oncology Group Study. Journal of clinical oncology : official journal of the American Society of Clinical Oncology 14(2):357-361. https://doi.org/10.1200/JCO.1996.14. 2.357

43. McMeekin DS, Gordon A, Fowler J, Melemed A, Buller R, Burke T, Bloss J, Sabbatini P (2003) A phase II trial of arzoxifene, a selective estrogen response modulator, in patients with recurrent or advanced endometrial cancer. Gynecol Oncol 90(1):64-69

44. Pandya KJ, Yeap BY, Weiner LM, Krook JE, Erban JK, Schinella RA, Davis TE (2001) Megestrol and tamoxifen in patients with advanced endometrial cancer: an Eastern Cooperative Oncology Group Study (E4882). Am J Clin Oncol 24(1):43-46

45. Piver MS, Barlow JJ, Lurain JR, Blumenson LE (1980) Medroxyprogesterone acetate (Depo-Provera) vs. hydroxyprogesterone caproate (Delalutin) in women with metastatic endometrial adenocarcinoma. Cancer 45(2):268-272

46. Podratz KC, O'Brien PC, Malkasian GD Jr, Decker DG, Jefferies JA, Edmonson JH (1985) Effects of progestational agents in treatment of endometrial carcinoma. Obstet Gynecol 66(1):106-110

47. Rose PG, Brunetto VL, VanLe L, Bell J, Walker JL, Lee RB (2000) A phase II trial of anastrozole in advanced recurrent or persistent endometrial carcinoma: a Gynecologic Oncology Group study. Gynecol Oncol 78(2):212-216. https://doi.org/10. 1006/gyno.2000.5865

48. Thigpen JT, Brady MF, Alvarez RD, Adelson MD, Homesley HD, Manetta A, Soper JT, Given FT (1999) Oral medroxyprogesterone acetate in the treatment of advanced or recurrent endometrial carcinoma: a dose-response study by the Gynecologic Oncology Group. J Clin Oncol : Official Journal of the American Society of Clinical Oncology 17(6):1736-1744. https://doi.org/10.1200/ JCO.1999.17.6.1736

49. Thigpen T, Brady MF, Homesley HD, Soper JT, Bell J (2001) Tamoxifen in the treatment of advanced or recurrent endometrial carcinoma: a Gynecologic Oncology Group study. J Clin Oncol : Official Journal of the American Society of Clinical Oncology 19(2):364-367. https://doi.org/10.1200/JCO.2001.19.2.364
50. Whitney CW, Brunetto VL, Zaino RJ, Lentz SS, Sorosky J, Armstrong DK, Lee RB, Gynecologic Oncology Groups (2004) Phase II study of medroxyprogesterone acetate plus tamoxifen in advanced endometrial carcinoma: a Gynecologic Oncology Group study. Gynecol Oncol 92(1):4-9

51. Battista MJ, Schmidt M, Eichbaum M, Almstedt K, Heimes AS, Mallmann P, Hoffmann G, Steiner E (2015) Management of recurrent or metastatic endometrial cancer in Germany: results of the nationwide AGO pattern of care studies from the years 2013, 2009 and 2006. Arch Gynecol Obstet 292(6):1355-1360. https://doi. org/10.1007/s00404-015-3786-y

52. Lee WL, Yen MS, Chao KC, Yuan CC, Ng HT, Chao HT, Lee FK, Wang PH (2014) Hormone therapy for patients with advanced or recurrent endometrial cancer. J Chin Med Assoc 77(5):221-226. https://doi.org/10.1016/j.jcma.2014.02.007

53. Temkin SM, Fleming G (2009) Current treatment of metastatic endometrial cancer. Cancer Control 16(1):38-45

54. Fannon SA, Vidaver RM, Marts SA (2001) An abridged history of sex steroid hormone receptor action. J Appl Physiol (1985) 91(4): 1854-1859. https://doi.org/10.1152/jappl.2001.91.4.1854

55. Walter P, Green S, Greene G, Krust A, Bornert JM, Jeltsch JM, Staub A, Jensen E, Scrace G, Waterfield M et al (1985) Cloning of the human estrogen receptor cDNA. Proc Natl Acad Sci U S A 82(23):7889-7893

56. Kuiper GG, Enmark E, Pelto-Huikko M, Nilsson S, Gustafsson JA (1996) Cloning of a novel receptor expressed in rat prostate and ovary. Proc Natl Acad Sci U S A 93(12):5925-5930

57. Yi P, Wang Z, Feng Q, Pintilie GD, Foulds CE, Lanz RB, Ludtke SJ, Schmid MF, Chiu W, O'Malley BW (2015) Structure of a biologically active estrogen receptor-coactivator complex on DNA. Mol Cell 57(6):1047-1058. https://doi.org/10.1016/j. molcel.2015.01.025

58. Schwabe JW, Chapman L, Finch JT, Rhodes D (1993) The crystal structure of the estrogen receptor DNA-binding domain bound to DNA: how receptors discriminate between their response elements. Cell 75(3):567-578

59. Zwart W, de Leeuw R, Rondaij M, Neefjes J, Mancini MA, Michalides R (2010) The hinge region of the human estrogen receptor determines functional synergy between AF-1 and AF-2 in the quantitative response to estradiol and tamoxifen. J Cell Sci 123(Pt 8):1253-1261. https://doi.org/10.1242/jcs.061135

60. Tanenbaum DM, Wang Y, Williams SP, Sigler PB (1998) Crystallographic comparison of the estrogen and progesterone receptor's ligand binding domains. Proc Natl Acad Sci U S A 95(11):5998-6003

61. Danielian PS, White R, Lees JA, Parker MG (1992) Identification of a conserved region required for hormone dependent transcriptional activation by steroid hormone receptors. EMBO J 11(3): 1025-1033

62. Hewitt SC, Korach KS (2002) Estrogen receptors: structure, mechanisms and function. Rev Endocr Metab Disord 3(3):193200

63. Hapangama DK, Kamal AM, Bulmer JN (2015) Estrogen receptor beta: the guardian of the endometrium. Hum Reprod Update 21(2):174-193. https://doi.org/10.1093/humupd/dmu053

64. Carmeci C, Thompson DA, Ring HZ, Francke U, Weigel RJ (1997) Identification of a gene (GPR30) with homology to the G-protein-coupled receptor superfamily associated with estrogen receptor expression in breast cancer. Genomics 45(3):607-617. https://doi.org/10.1006/geno.1997.4972

65. Owman C, Blay P, Nilsson C, Lolait SJ (1996) Cloning of human cDNA encoding a novel heptahelix receptor expressed in Burkitt's lymphoma and widely distributed in brain and peripheral tissues. Biochem Biophys Res Commun 228(2):285-292. https://doi.org/ 10.1006/bbrc.1996.1654 
66. Revankar CM, Cimino DF, Sklar LA, Arterburn JB, Prossnitz ER (2005) A transmembrane intracellular estrogen receptor mediates rapid cell signaling. Science 307(5715):1625-1630. https://doi. org/10.1126/science. 1106943

67. Thomas P, Pang Y, Filardo EJ, Dong J (2005) Identity of an estrogen membrane receptor coupled to a $G$ protein in human breast cancer cells. Endocrinology 146(2):624-632. https://doi.org/10. 1210/en.2004-1064

68. Skrzypczak M, Schuler S, Lattrich C, Ignatov A, Ortmann O, Treeck O (2013) G protein-coupled estrogen receptor (GPER) expression in endometrial adenocarcinoma and effect of agonist G-1 on growth of endometrial adenocarcinoma cell lines. Steroids 78(11):1087-1091. https://doi.org/10.1016/j.steroids.2013.07.007

69. Losel R, Wehling M (2003) Nongenomic actions of steroid hormones. Nat Rev Mol Cell Biol 4(1):46-56. https://doi.org/10. 1038/nrm1009

70. Pietras RJ, Szego CM (1977) Specific binding sites for oestrogen at the outer surfaces of isolated endometrial cells. Nature 265(5589):69-72

71. Kahlert S, Nuedling S, van Eickels M, Vetter H, Meyer R, Grohe C (2000) Estrogen receptor alpha rapidly activates the IGF-1 receptor pathway. J Biol Chem 275(24):18447-18453. https://doi. org/10.1074/jbc.M910345199

72. Ui H, Mueller GC (1963) The role of RNA synthesis in early estrogen action. Proc Natl Acad Sci U S A 50:256-260

73. Kumar V, Chambon P (1988) The estrogen receptor binds tightly to its responsive element as a ligand-induced homodimer. Cell 55(1):145-156

74. Klein-Hitpass L, Schorpp M, Wagner U, Ryffel GU (1986) An estrogen-responsive element derived from the $5^{\prime}$ flanking region of the Xenopus vitellogenin A2 gene functions in transfected human cells. Cell 46(7):1053-1061

75. Walker P, Germond JE, Brown-Luedi M, Givel F, Wahli W (1984) Sequence homologies in the region preceding the transcription initiation site of the liver estrogen-responsive vitellogenin and apo-VLDLII genes. Nucleic Acids Res 12(22):8611-8626

76. Welboren WJ, van Driel MA, Janssen-Megens EM, van Heeringen SJ, Sweep FC, Span PN, Stunnenberg HG (2009) ChIP-Seq of ERalpha and RNA polymerase II defines genes differentially responding to ligands. EMBO J 28(10):1418-1428. https://doi.org/10.1038/emboj.2009.88

77. Joseph R, Orlov YL, Huss M, Sun W, Kong SL, Ukil L, Pan YF, Li G, Lim M, Thomsen JS, Ruan Y, Clarke ND, Prabhakar S, Cheung E, Liu ET (2010) Integrative model of genomic factors for determining binding site selection by estrogen receptor-alpha. Mol Syst Biol 6:456. https://doi.org/10.1038/msb.2010.109

78. Gertz J, Savic D, Varley KE, Partridge EC, Safi A, Jain P, Cooper GM, Reddy TE, Crawford GE, Myers RM (2013) Distinct properties of cell-type-specific and shared transcription factor binding sites. Mol Cell 52(1):25-36. https://doi.org/10.1016/j.molcel. 2013.08.037

79. Krishnan V, Wang X, Safe S (1994) Estrogen receptor-Sp1 complexes mediate estrogen-induced cathepsin $\mathrm{D}$ gene expression in MCF-7 human breast cancer cells. J Biol Chem 269(22):1591215917

80. Safe S, Kim K (2008) Non-classical genomic estrogen receptor (ER)/specificity protein and ER/activating protein-1 signaling pathways. J Mol Endocrinol 41(5):263-275. https://doi.org/10. 1677/JME-08-0103

81. Heldring N, Isaacs GD, Diehl AG, Sun M, Cheung E, Ranish JA, Kraus WL (2011) Multiple sequence-specific DNA-binding proteins mediate estrogen receptor signaling through a tethering pathway. Mol Endocrinol 25(4):564-574. https://doi.org/10.1210/me. 2010-0425

82. Gertz J, Reddy TE, Varley KE, Garabedian MJ, Myers RM (2012) Genistein and bisphenol A exposure cause estrogen receptor 1 to bind thousands of sites in a cell type-specific manner. Genome Res 22(11):2153-2162. https://doi.org/10.1101/gr.135681.111

83. Droog M, Nevedomskaya E, Kim Y, Severson T, Flach KD, Opdam M, Schuurman K, Gradowska P, Hauptmann M, Dackus G, Hollema H, Mourits M, Nederlof P, van Boven H, Linn SC, Wessels L, van Leeuwen FE, Zwart W (2016) Comparative cistromics reveals genomic cross-talk between FOXA1 and ERalpha in tamoxifen-associated endometrial carcinomas. Cancer Res 76(13):3773-3784. https://doi.org/10.1158/00085472.CAN-14-1813

84. He HH, Meyer CA, Chen MW, Jordan VC, Brown M, Liu XS (2012) Differential DNase I hypersensitivity reveals factordependent chromatin dynamics. Genome Res 22(6):1015-1025. https://doi.org/10.1101/gr.133280.111

85. Carroll JS, Meyer CA, Song J, Li W, Geistlinger TR, Eeckhoute J, Brodsky AS, Keeton EK, Fertuck KC, Hall GF, Wang Q, Bekiranov S, Sementchenko V, Fox EA, Silver PA, Gingeras TR, Liu XS, Brown M (2006) Genome-wide analysis of estrogen receptor binding sites. Nat Genet 38(11):1289-1297. https://doi. org/10.1038/ng1901

86. Lin CY, Vega VB, Thomsen JS, Zhang T, Kong SL, Xie M, Chiu KP, Lipovich L, Barnett DH, Stossi F, Yeo A, George J, Kuznetsov VA, Lee YK, Charn TH, Palanisamy N, Miller LD, Cheung E, Katzenellenbogen BS, Ruan Y, Bourque G, Wei CL, Liu ET (2007) Whole-genome cartography of estrogen receptor alpha binding sites. PLoS Genet 3(6):e87. https://doi.org/10.1371/ journal.pgen.0030087

87. Fullwood MJ, Liu MH, Pan YF, Liu J, Xu H, Mohamed YB, Orlov YL, Velkov S, Ho A, Mei PH, Chew EG, Huang PY, Welboren WJ, Han Y, Ooi HS, Ariyaratne PN, Vega VB, Luo Y, Tan PY, Choy PY, Wansa KD, Zhao B, Lim KS, Leow SC, Yow JS, Joseph R, Li H, Desai KV, Thomsen JS, Lee YK, Karuturi RK, Herve T, Bourque G, Stunnenberg HG, Ruan X, CacheuxRataboul V, Sung WK, Liu ET, Wei CL, Cheung E, Ruan Y (2009) An oestrogen-receptor-alpha-bound human chromatin interactome. Nature 462(7269):58-64. https://doi.org/10.1038/ nature 08497

88. Coons LA, Hewitt SC, Burkholder AB, McDonnell DP, Korach KS (2017) DNA sequence constraints define functionally active steroid nuclear receptor binding sites in chromatin. Endocrinology 158(10):3212-3234. https://doi.org/10.1210/en.2017-00468

89. Hah N, Murakami S, Nagari A, Danko CG, Kraus WL (2013) Enhancer transcripts mark active estrogen receptor binding sites. Genome Res 23(8):1210-1223. https://doi.org/10.1101/gr. 152306.112

90. Carleton JB, Berrett KC, Gertz J (2017) Multiplex enhancer interference reveals collaborative control of gene regulation by estrogen receptor alpha-bound enhancers. Cell Syst 5:333-344.e5. https://doi.org/10.1016/j.cels.2017.08.011

91. Carleton JB, Berrett KC, Gertz J (2018) Dissection of enhancer function using multiplex CRISPR-based enhancer interference in cell lines. J Vis Exp. https://doi.org/10.3791/57883

92. Hurtado A, Holmes KA, Ross-Innes CS, Schmidt D, Carroll JS (2011) FOXA1 is a key determinant of estrogen receptor function and endocrine response. Nat Genet 43(1):27-33. https://doi.org/ $10.1038 /$ ng. 730

93. Theodorou V, Stark R, Menon S, Carroll JS (2013) GATA3 acts upstream of FOXA1 in mediating ESR1 binding by shaping enhancer accessibility. Genome Res 23(1):12-22. https://doi.org/10. 1101/gr.139469.112

94. Metivier R, Penot G, Flouriot G, Pakdel F (2001) Synergism between ERalpha transactivation function $1(\mathrm{AF}-1)$ and AF-2 mediated by steroid receptor coactivator protein-1: requirement for the AF-1 alpha-helical core and for a direct interaction between the Nand C-terminal domains. Mol Endocrinol 15(11):1953-1970. https://doi.org/10.1210/mend.15.11.0727 
95. Chen H, Lin RJ, Schiltz RL, Chakravarti D, Nash A, Nagy L, Privalsky ML, Nakatani Y, Evans RM (1997) Nuclear receptor coactivator ACTR is a novel histone acetyltransferase and forms a multimeric activation complex with $\mathrm{P} / \mathrm{CAF}$ and $\mathrm{CBP} / \mathrm{p} 300$. Cell 90(3):569-580

96. Hong H, Kohli K, Trivedi A, Johnson DL, Stallcup MR (1996) GRIP1, a novel mouse protein that serves as a transcriptional coactivator in yeast for the hormone binding domains of steroid receptors. Proc Natl Acad Sci U S A 93(10):4948-4952

97. Onate SA, Tsai SY, Tsai MJ, O'Malley BW (1995) Sequence and characterization of a coactivator for the steroid hormone receptor superfamily. Science 270(5240):1354-1357

98. Chen JD, Evans RM (1995) A transcriptional co-repressor that interacts with nuclear hormone receptors. Nature 377(6548): 454-457. https://doi.org/10.1038/377454a0

99. Horlein AJ, Naar AM, Heinzel T, Torchia J, Gloss B, Kurokawa R, Ryan A, Kamei Y, Soderstrom M, Glass CK et al (1995) Ligand-independent repression by the thyroid hormone receptor mediated by a nuclear receptor co-repressor. Nature 377(6548): 397-404. https://doi.org/10.1038/377397a0

100. Shang Y, Hu X, DiRenzo J, Lazar MA, Brown M (2000) Cofactor dynamics and sufficiency in estrogen receptor-regulated transcription. Cell 103(6):843-852

101. Brzozowski AM, Pike AC, Dauter Z, Hubbard RE, Bonn T, Engstrom O, Ohman L, Greene GL, Gustafsson JA, Carlquist M (1997) Molecular basis of agonism and antagonism in the oestrogen receptor. Nature 389(6652):753-758. https://doi.org/ $10.1038 / 39645$

102. Fisher B, Costantino JP, Redmond CK, Fisher ER, Wickerham DL, Cronin WM (1994) Endometrial cancer in tamoxifen-treated breast cancer patients: findings from the National Surgical Adjuvant Breast and Bowel Project (NSABP) B-14. J Natl Cancer Inst 86(7):527-537

103. Shiau AK, Barstad D, Loria PM, Cheng L, Kushner PJ, Agard DA, Greene GL (1998) The structural basis of estrogen receptor/ coactivator recognition and the antagonism of this interaction by tamoxifen. Cell 95(7):927-937

104. Gottardis MM, Robinson SP, Satyaswaroop PG, Jordan VC (1988) Contrasting actions of tamoxifen on endometrial and breast tumor growth in the athymic mouse. Cancer Res 48(4):812-815

105. Shang Y, Brown M (2002) Molecular determinants for the tissue specificity of SERMs. Science 295(5564):2465-2468. https://doi. org $/ 10.1126 /$ science. 1068537

106. Droog M, Nevedomskaya E, Dackus GM, Fles R, Kim Y, Hollema H, Mourits MJ, Nederlof PM, van Boven HH, Linn SC, van Leeuwen FE, Wessels LF, Zwart W (2017) Estrogen receptor alpha wields treatment-specific enhancers between morphologically similar endometrial tumors. Proc Natl Acad Sci U S A 114(8):E1316-E1E25. https://doi.org/10.1073/pnas. 1615233114

107. Mohammed H, D'Santos C, Serandour AA, Ali HR, Brown GD, Atkins A, Rueda OM, Holmes KA, Theodorou V, Robinson JL, Zwart W, Saadi A, Ross-Innes CS, Chin SF, Menon S, Stingl J, Palmieri C, Caldas C, Carroll JS (2013) Endogenous purification reveals GREB1 as a key estrogen receptor regulatory factor. Cell Rep 3(2):342-349. https://doi.org/10.1016/j.celrep.2013.01.010

108. Lobingier BT, Huttenhain R, Eichel K, Miller KB, Ting AY, von Zastrow M, Krogan NJ (2017) An approach to spatiotemporally resolve protein interaction networks in living cells. Cell 169(2): 350-360 e12. https://doi.org/10.1016/j.cell.2017.03.022

109. Roux KJ, Kim DI, Burke B (2013) BioID: a screen for proteinprotein interactions. Curr Protoc Protein Sci 74:Unit 19 23. https:// doi.org/10.1002/0471140864.ps1923s 74

110. Sikora MJ (2016) Family matters: collaboration and conflict among the steroid receptors raises a need for group therapy.
Endocrinology 157(12):4553-4560. https://doi.org/10.1210/en. 2016-1778

111. Vahrenkamp JM, Yang CH, Rodriguez AC, Almomen A, Berrett $\mathrm{KC}$, Trujillo AN, Guillen KP, Welm BE, Jarboe EA, JanatAmsbury MM, Gertz J (2018) Clinical and genomic crosstalk between glucocorticoid receptor and estrogen receptor alpha in endometrial cancer. Cell Rep 22(11):2995-3005. https://doi.org/ 10.1016/j.celrep.2018.02.076

112. Prange-Kiel J, Rune GM, Zwirner M, Wallwiener D, Kiesel L (2001) Regulation of estrogen receptor alpha and progesterone receptor (isoform $\mathrm{A}$ and $\mathrm{B}$ ) expression in cultured human endometrial cells. Exp Clin Endocrinol Diabetes 109(4):231-237. https://doi.org/10.1055/s-2001-15111

113. Mohammed H, Russell IA, Stark R, Rueda OM, Hickey TE, Tarulli GA, Serandour AA, Birrell SN, Bruna A, Saadi A, Menon S, Hadfield J, Pugh M, Raj GV, Brown GD, D'Santos C, Robinson JL, Silva G, Launchbury R, Perou CM, Stingl J, Caldas C, Tilley WD, Carroll JS (2015) Progesterone receptor modulates ERalpha action in breast cancer. Nature 523(7560):313-317. https://doi.org/10.1038/nature14583

114. Singhal H, Greene ME, Tarulli G, Zarnke AL, Bourgo RJ, Laine M, Chang YF, Ma S, Dembo AG, Raj GV, Hickey TE, Tilley WD, Greene GL (2016) Genomic agonism and phenotypic antagonism between estrogen and progesterone receptors in breast cancer. Sci Adv 2(6):e1501924. https://doi.org/10.1126/sciadv.1501924

115. Bever AT, Hisaw FL, Velardo JT (1956) Inhibitory action of desoxycorticosterone acetate, cortisone acetate, and testosterone on uterine growth induced by estradiol-17beta. Endocrinology 59(2):165-169. https://doi.org/10.1210/endo-59-2-165

116. Bitman J, Cecil HC (1967) Differential inhibition by cortisol of estrogen-stimulated uterine responses. Endocrinology 80(3):423429. https://doi.org/10.1210/endo-80-3-423

117. Pan D, Kocherginsky M, Conzen SD (2011) Activation of the glucocorticoid receptor is associated with poor prognosis in estrogen receptor-negative breast cancer. Cancer Res 71(20):6360 6370. https://doi.org/10.1158/0008-5472.CAN-11-0362

118. Miranda TB, Voss TC, Sung MH, Baek S, John S, Hawkins M, Grontved L, Schiltz RL, Hager GL (2013) Reprogramming the chromatin landscape: interplay of the estrogen and glucocorticoid receptors at the genomic level. Cancer Res 73(16):5130-5139. https://doi.org/10.1158/0008-5472.CAN-13-0742

119. Pakdel F, Reese JC, Katzenellenbogen BS (1993) Identification of charged residues in an N-terminal portion of the hormone-binding domain of the human estrogen receptor important in transcriptional activity of the receptor. Mol Endocrinol 7(11):1408-1417. https://doi.org/10.1210/mend.7.11.8114756

120. Weis KE, Ekena K, Thomas JA, Lazennec G, Katzenellenbogen BS (1996) Constitutively active human estrogen receptors containing amino acid substitutions for tyrosine 537 in the receptor protein. Mol Endocrinol 10(11):1388-1398. https://doi.org/10. 1210/mend.10.11.8923465

121. Zhang QX, Borg A, Wolf DM, Oesterreich S, Fuqua SA (1997) An estrogen receptor mutant with strong hormone-independent activity from a metastatic breast cancer. Cancer Res 57(7):1244 1249

122. Toy W, Weir H, Razavi P, Lawson M, Goeppert AU, Mazzola AM, Smith A, Wilson J, Morrow C, Wong WL, De Stanchina E, Carlson KE, Martin TS, Uddin S, Li Z, Fanning S, Katzenellenbogen JA, Greene G, Baselga J, Chandarlapaty S (2017) Activating ESR1 mutations differentially affect the efficacy of ER antagonists. Cancer Discov 7(3):277-287. https://doi. org/10.1158/2159-8290.CD-15-1523

123. Fanning SW, Mayne CG, Dharmarajan V, Carlson KE, Martin TA, Novick SJ, Toy W, Green B, Panchamukhi S, Katzenellenbogen BS, Tajkhorshid E, Griffin PR, Shen Y, Chandarlapaty S, Katzenellenbogen JA, Greene GL (2016) Estrogen receptor alpha 
somatic mutations Y537S and D538G confer breast cancer endocrine resistance by stabilizing the activating function-2 binding conformation. Elife 5:e12792. https://doi.org/10.7554/eLife. 12792

124. Fuqua SA, Gu G, Rechoum Y (2014) Estrogen receptor (ER) alpha mutations in breast cancer: hidden in plain sight. Breast Cancer Res Treat 144(1):11-19. https://doi.org/10.1007/s10549014-2847-4

125. Jeselsohn R, Bergholz JS, Pun M, Cornwell M, Liu W, Nardone A, Xiao T, Li W, Qiu X, Buchwalter G, Feiglin A, Abell-Hart K, Fei T, Rao P, Long H, Kwiatkowski N, Zhang T, Gray N, Melchers D, Houtman R, Liu XS, Cohen O, Wagle N, Winer EP, Zhao J, Brown M (2018) Allele-specific chromatin recruitment and therapeutic vulnerabilities of ESR1 activating mutations. Cancer Cell 33(2):173-186 e5. https://doi.org/10.1016/j.ccell.2018.01.004

126. Jeselsohn R, Yelensky R, Buchwalter G, Frampton G, MericBernstam F, Gonzalez-Angulo AM, Ferrer-Lozano J, PerezFidalgo JA, Cristofanilli M, Gomez H, Arteaga CL, Giltnane J, Balko JM, Cronin MT, Jarosz M, Sun J, Hawryluk M, Lipson D, Otto G, Ross JS, Dvir A, Soussan-Gutman L, Wolf I, Rubinek T, Gilmore L, Schnitt S, Come SE, Pusztai L, Stephens P, Brown M, Miller VA (2014) Emergence of constitutively active estrogen receptor-alpha mutations in pretreated advanced estrogen receptor-positive breast cancer. Clin Cancer Res : an official journal of the American Association for Cancer Research 20(7):17571767. https://doi.org/10.1158/1078-0432.CCR-13-2332

127. Katzenellenbogen JA, Mayne CG, Katzenellenbogen BS, Greene GL, Chandarlapaty S (2018) Structural underpinnings of oestrogen receptor mutations in endocrine therapy resistance. Nat Rev Cancer 18(6):377-388. https://doi.org/10.1038/s41568018-0001-Z

128. Merenbakh-Lamin K, Ben-Baruch N, Yeheskel A, Dvir A, Soussan-Gutman L, Jeselsohn R, Yelensky R, Brown M, Miller VA, Sarid D, Rizel S, Klein B, Rubinek T, Wolf I (2013) D538G mutation in estrogen receptor-alpha: a novel mechanism for acquired endocrine resistance in breast cancer. Cancer Res 73(23): 6856-6864. https://doi.org/10.1158/0008-5472.CAN-13-1197

129. Robinson DR, Wu YM, Vats P, Su F, Lonigro RJ, Cao X, KalyanaSundaram S, Wang R, Ning Y, Hodges L, Gursky A, Siddiqui J, Tomlins SA, Roychowdhury S, Pienta KJ, Kim SY, Roberts JS, Rae JM, Van Poznak CH, Hayes DF, Chugh R, Kunju LP, Talpaz M, Schott AF, Chinnaiyan AM (2013) Activating ESR1 mutations in hormone-resistant metastatic breast cancer. Nat Genet 45(12): 1446-1451. https://doi.org/10.1038/ng.2823

130. Toy W, Shen Y, Won H, Green B, Sakr RA, Will M, Li Z, Gala K, Fanning S, King TA, Hudis C, Chen D, Taran T, Hortobagyi G, Greene G, Berger M, Baselga J, Chandarlapaty S (2013) ESR1 ligand-binding domain mutations in hormone-resistant breast cancer. Nat Genet 45(12):1439-1445. https://doi.org/10.1038/ng.2822

131. Zhao Y, Laws MJ, Guillen VS, Ziegler Y, Min J, Sharma A, Kim SH, Chu D, Park BH, Oesterreich S, Mao C, Shapiro DJ, Nettles KW, Katzenellenbogen JA, Katzenellenbogen BS (2017) Structurally novel antiestrogens elicit differential responses from constitutively active mutant estrogen receptors in breast cancer cells and tumors. Cancer Res 77(20):5602-5613. https://doi.org/ 10.1158/0008-5472.CAN-17-1265

132. Hoadley KA, Yau C, Hinoue T, Wolf DM, Lazar AJ, Drill E, Shen R, Taylor AM, Cherniack AD, Thorsson V, Akbani R, Bowlby R, Wong CK, Wiznerowicz M, Sanchez-Vega F, Robertson AG,
Schneider BG, Lawrence MS, Noushmehr H, Malta TM, Stuart JM, Benz CC, Laird PW, Cancer Genome Atlas N (2018) Cell-oforigin patterns dominate the molecular classification of 10,000 tumors from 33 types of cancer. Cell 173(2):291-304 e6. https:// doi.org/10.1016/j.cell.2018.03.022

133. Li S, Shen D, Shao J, Crowder R, Liu W, Prat A, He X, Liu S, Hoog J, Lu C, Ding L, Griffith OL, Miller C, Larson D, Fulton RS, Harrison M, Mooney T, JF MM, Luo J, Tao Y, Goncalves R, Schlosberg C, Hiken JF, Saied L, Sanchez C, Giuntoli T, Bumb C, Cooper C, Kitchens RT, Lin A, Phommaly C, Davies SR, Zhang J, Kavuri MS, McEachern D, Dong YY, Ma C, Pluard T, Naughton M, Bose R, Suresh R, McDowell R, Michel L, Aft R, Gillanders W, De Schryver K, Wilson RK, Wang S, Mills GB, Gonzalez-Angulo A, Edwards JR, Maher C, Perou CM, Mardis ER, Ellis MJ (2013) Endocrine-therapy-resistant ESR1 variants revealed by genomic characterization of breast-cancer-derived xenografts. Cell Rep 4(6):1116-1130. https://doi.org/10.1016/j. celrep.2013.08.022

134. Backes FJ, Walker CJ, Goodfellow PJ, Hade EM, Agarwal G, Mutch D, Cohn DE, Suarez AA (2016) Estrogen receptor-alpha as a predictive biomarker in endometrioid endometrial cancer. Gynecol Oncol 141(2):312-317. https://doi.org/10.1016/j.ygyno. 2016.03.006

135. Blanchard Z, Vahrenkamp JM, Berrett KC, Arnesen S, Gertz J (2018) Estrogen-independent molecular actions of mutant estrogen receptor alpha in endometrial cancer. bioRxiv. https://doi.org/ 10.1101/369165

136. Bahreini A, Li Z, Wang P, Levine KM, Tasdemir N, Cao L, Weir HM, Puhalla SL, Davidson NE, Stern AM, Chu D, Park BH, Lee AV, Oesterreich S (2017) Mutation site and context dependent effects of ESR1 mutation in genome-edited breast cancer cell models. Breast Cancer Res : BCR 19(1):60. https://doi.org/10. 1186/s13058-017-0851-4

137. Szwarc MM, Lydon JP, O'Malley BW (2015) Steroid receptor coactivators as therapeutic targets in the female reproductive system. J Steroid Biochem Mol Biol 154:32-38. https://doi.org/10. 1016/j.jsbmb.2015.06.010

138. O'Hara AJ, Bell DW (2012) The genomics and genetics of endometrial cancer. Adv Genomics Genet 2012(2):33-47. https://doi. org/10.2147/AGG.S28953

139. Franco HL, Nagari A, Kraus WL (2015) TNFalpha signaling exposes latent estrogen receptor binding sites to alter the breast cancer cell transcriptome. Mol Cell 58(1):21-34. https://doi.org/10. 1016/j.molcel.2015.02.001

140. Lupien M, Meyer CA, Bailey ST, Eeckhoute J, Cook J, Westerling T, Zhang X, Carroll JS, Rhodes DR, Liu XS, Brown M (2010) Growth factor stimulation induces a distinct ER(alpha) cistrome underlying breast cancer endocrine resistance. Genes Dev 24(19): 2219-2227. https://doi.org/10.1101/gad.1944810

141. Ross-Innes CS, Stark R, Teschendorff AE, Holmes KA, Ali HR, Dunning MJ, Brown GD, Gojis O, Ellis IO, Green AR, Ali S, Chin SF, Palmieri C, Caldas C, Carroll JS (2012) Differential oestrogen receptor binding is associated with clinical outcome in breast cancer. Nature 481(7381):389-393. https://doi.org/10.1038/ nature 10730

142. Lortet-Tieulent J, Ferlay J, Bray F, Jemal A (2018) International patterns and trends in endometrial cancer incidence, 1978-2013. J Natl Cancer Inst 110(4):354-361. https://doi.org/10.1093/jnci/ djx 214 